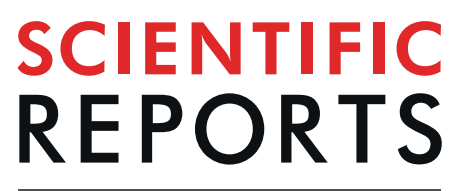

natureresearch

\title{
Association between Serum Calcium and Risk of Cardiometabolic Disease among Community-dwelling Adults in Taiwan
}

\author{
Cheng-Wai Chou ${ }^{1,2}$, Wen-Hui Fang ${ }^{1}$, Yuan-Yuei Chen ${ }^{1,3}$, Chung-Ching Wang ${ }^{1,3}$, \\ Tung-Wei $\mathrm{KaO}^{1,3,4}$, Chen-Jung Wu ${ }^{1,3,5}$ \& Wei-Liang Chen $\mathbb{1}^{1,3^{*}}$
}

Serum calcium, although only comprising $1 \%$ of total body calcium, is involved in intracellular signal pathways, vascular dilatation/constriction, and muscle contraction, which are crucial for insulin secretion, cholesterol catabolism, and blood pressure regulation. As far as we know, research on the relationship between serum calcium level and metabolic syndrome (MetS), diabetes, and hypertension in one longitudinal study is rare. Owing to the crucial role of serum calcium in human cardiometabolic physiology and lack of related study so far, this study aims to describe the relationship between serum calcium level and the incidence of MetS, diabetes, and hypertension. During the period 2010-2016, there are two parts to our study: cross-sectional analysis and longitudinal analysis. Logistic regression was applied for cross-sectional analysis of the association between serum calcium level or albumincorrected calcium (ACCA) and the prevalence of MetS, diabetes, or hypertension. Receiver operating characteristic (ROC) curve analysis was used for calculating of optimal cut-off value of serum calcium and ACCA. Cox proportional regression for development of MetS, diabetes, and hypertension according to different cut-off values of serum calcium level and ACCA were conducted. At baseline, there were 27,364 participants in our study. Serum calcium level had positive association with diabetes in the total population, male, and female. ACCA level had positive association with diabetes in the total population, male, and female. In unadjusted and multivariate Cox proportional hazard models, serum calcium level was associated with increased risk of incident MetS in the total population and male. ACCA was associated with increased risk of incident MetS in the total population and male. ACCA was associated with increased risk of incident diabetes in the total population and male participants. This study describes the relationship between serum calcium level and the incidence of MetS, diabetes, and hypertension. Higher serum calcium level is associated with increased risk of MetS, diabetes, and hypertension.

Metabolic syndrome (MetS), diabetes mellitus, and hypertension are three major health challenges in industrialized countries worldwide. According to the estimation of the International Diabetes Federation (IDF), the prevalence of MetS around the world is $25 \%^{1}$. The estimated number of people with diabetes in 2030 will be 366 million, and the number of adults with hypertension in 2025 is predicted to be 1.56 billion $^{2}$. Serum calcium, although only

\footnotetext{
${ }^{1}$ Division of Family Medicine, Department of Family and Community Medicine, Tri-Service General Hospital; and School of Medicine, National Defense Medical Center, Taipei, Taiwan, Republic of China. ${ }^{2}$ Department of Otorhinolaryngology Head and Neck Surgery, Taipei Veterans General Hospital, Taipei, Taiwan, Republic of China. ${ }^{3}$ Division of Geriatric Medicine, Department of Family and Community Medicine, Tri-Service General Hospital; and School of Medicine, National Defense Medical Center, Taipei, Taiwan, Republic of China. ${ }^{4}$ Graduate Institute of Clinical Medical, College of Medicine, National Taiwan University, Taipei, Taiwan, Republic of China. ${ }^{5}$ Division of Family Medicine, Department of Community Medicine, Taoyuan Armed Forces General Hospital, Taoyuan, Taiwan, Republic of China. *email: weiliang0508@gmail.com
} 
comprising $1 \%$ of total body calcium, is involved in intracellular signal pathways, vascular dilatation/constriction, and muscle contraction ${ }^{3}$. These functions are crucial for insulin secretion, cholesterol catabolism, and blood pressure regulation, which are important etiologies of MetS, diabetes, and hypertension. Hypertension occurs in $50 \%$ to $80 \%$ of patients with type 2 diabetes in the United States ${ }^{4}$. This high overlap rate can be explained by the common etiologies and mechanisms between MetS, diabetes, and hypertension, such as insulin resistance, inflammation, oxidative stress, and obesity ${ }^{5}$. Patients often suffer more than one of these diseases, accelerating the onset of complications. Owing to the crucial role serum calcium plays in MetS, diabetes, hypertension and the extensive overlap of these diseases, a longitudinal cohort study to estimate how well serum calcium predicts their incidences wound be interesting.

In Germany, Spain and Italy, for the healthcare system, the economic burden of MetS in patients with hypertension was estimated at $€ 24,427, € 1,900$ and $€ 4,877$ million and are expected to rise by $59 \%, 179 \%$ and $157 \%$ respectively by 2020 , most of the costs would be used on prevention of type 2 diabetes and cardiovascular incidents $^{6}$. In India, the age-standardized cardiovascular disease death rate is estimated to be 272 per 100,000 population, this number exceeded the global average. In addition, over the past two decades, there is a $59 \%$ increase in premature mortality because of cardiovascular disease in India ${ }^{7}$. In 2009, high blood glucose accounted for 14,900 deaths, or $10.4 \%$ of all deaths in Taiwan, whereas high blood pressure accounted for 11,190 deaths ${ }^{8}$. More studies should be conducted to provide better understanding of cardiometabolic diseases, since they have posed a very serious threat to the human health worldwide and a heavy burden to the economy. As far as we know, there have been researches on association between serum calcium level and MetS, diabetes, and hypertension respectively, but simultaneous research on the relationship between serum calcium level and MetS, diabetes, and hypertension in one longitudinal study is rare ${ }^{9-13}$. This longitudinal study is a pioneering study that simultaneously considers incident MetS, diabetes, and hypertension according to serum calcium level. Calcium level is corrected using albumin to better present the actual calcium concentration in serum.

\section{Results}

Age and metabolic parameters as related to serum calcium level. Age and metabolic parameters as related to serum calcium level are shown in Table 1. Subjects with serum calcium or ACCA level greater than the cut-off values had higher body mass index (BMI), total cholesterol, triglycerides, low-density lipid cholesterol (LDL-C), creatinine, uric acid, and albumin.

Relationship between serum calcium, metabolic syndrome, diabetes, and hypertension. Relationship between serum calcium level and MetS, diabetes, and hypertension were analyzed by logistic regression in Table 2. The statistical significance of the association between serum calcium level and MetS in the total population was at borderline, the odd ratio $(\mathrm{OR})$ was 1.13 (95\% CI: 1.00-1.29 P=0.057) in model 2. Serum calcium level had positive association with diabetes in the total population, male, and female, ORs were 1.40 (95\% CI: $1.16-1.68 \mathrm{P}<0.001), 1.35$ (95\% CI: $1.10-1.67 \mathrm{P}=0.005)$, and 1.50 (95\% CI: $1.03-2.18 \mathrm{P}=0.036)$ in model 2. Serum calcium level had positive association with hypertension in the total population, OR was 1.14 (95\% CI: $1.03-1.27 \mathrm{P}=0.013)$ in model 2 .

Relationship between albumin-corrected calcium, metabolic syndrome, diabetes, and hypertension. Relationship between ACCA level and MetS, diabetes, and hypertension were analyzed by logistic regression in Table 3. ACCA level had positive association with MetS in the total population, male, and female, ORs were 1.20 (95\% CI: $1.03-1.40 \mathrm{P}=0.022), 1.30$ (95\% CI: $1.03-1.64 \mathrm{P}=0.026)$, and 1.08 (95\% CI: 0.87-1.34 P=0.049) for model 2. ACCA level had positive association with diabetes in the total population, male, and female, ORs were 1.76 (95\% CI: $1.41-2.20 \mathrm{P}<0.001$ ), 1.68 (95\% CI: 1.17-2.42 P=0.005), and 1.86 (95\% CI: $1.39-2.49 \mathrm{P}<0.001)$ for models 2. ACCA level had positive association with hypertension in the total population, OR was 1.15 (95\% CI: $1.01-1.30 \mathrm{P}=0.037$ ) for model 2 .

Multivariate hazard ratios of future metabolic syndrome, diabetes, hypertension by serum calcium level. The results of using serum calcium level on prediction of future MetS, diabetes, and hypertension were shown in Table 4. High serum calcium level is associated with increased risk of incident MetS in the total population and male, hazard ratios (HRs) were 1.73 (95\% CI: $1.07-2.79 \mathrm{P}=0.024)$ and 1.76 (95\% CI: $1.07-2.89$ $\mathrm{P}=0.027$ ) for model 2 . Serum calcium level is associated with increased risk of incident diabetes in the total population and male, HRs were 2.51 (95\% CI: $1.30-4.83 \mathrm{P}=0.006)$ and 2.86 (95\% CI: $1.45-5.66 \mathrm{P}=0.003)$ for model 2. Serum calcium level is associated with increased risk of hypertension in the total population, male, and female, HRs were 1.76 (95\% CI: $1.22-2.55 \mathrm{P}=0.003), 1.72$ (95\% CI: $1.17-2.50 \mathrm{P}=0.006)$, and 5.35 (95\% CI: 1.14-25.03 $\mathrm{P}=0.033$ ) for model 2. There were too little samples for the development of MetS and diabetes in the female subgroup, the multivariate analysis was unable to perform.

Multivariate hazard ratios of future metabolic syndrome, diabetes, hypertension by albumin corrected calcium level. The results of using ACCA on prediction of future MetS, diabetes, and hypertension were shown in Table 5. High ACCA is associated with increased risk of incident MetS in the total population and the p-value was at borderline for statistical significance in the male population, HRs were 1.69 (95\% CI: 1.04-2.74 $\mathrm{P}=0.035)$ and 1.63 (95\% CI: 0.99-2.69 P =0.057) for model 2. ACCA is associated with increased risk of incident diabetes in the total population and male, HRs were 2.95 (95\% CI: 1.43-6.07 P=0.003) and 3.39 (95\% CI: $1.57-7.33 \mathrm{P}=0.002)$ for model 2 . ACCA is associated with increased risk of hypertension in the total population, male, and female, HRs were 2.07 (95\% CI: 1.41-3.02 P < 0.001), 1.72 (95\% CI: 1.17-2.50 P=0.006), and 11.40 (95\% CI: $3.22-40.44 \mathrm{P}<0.001$ ) for model 2 . There were too little samples for the development of diabetes in the female subgroup, the multivariate analysis was unable to perform. 


\begin{tabular}{|c|c|c|c|}
\hline **Continuous variables, mean (SD) & $\begin{array}{l}\text { Serum calcium }>\text { cut-off } \\
\text { value }(\mathrm{N}=12367)\end{array}$ & $\begin{array}{l}\text { Serum calcium } \leq \text { cut-off } \\
\text { value }(N=14997)\end{array}$ & P-value \\
\hline$* A C C A(m g / d L)$ & $9.07(0.29)$ & $8.84(0.34)$ & $<0.001$ \\
\hline Age (years) & $42.63(12.76)$ & $42.65(13.19)$ & 0.907 \\
\hline *Body mass index (BMI) $\left(\mathrm{kg} / \mathrm{m}^{2}\right)$ & $24.74(3.68)$ & $23.25(4.03)$ & $<0.001$ \\
\hline$*$ Total cholesterol $(\mathrm{mg} / \mathrm{dL})$ & $187.42(35.79)$ & $184.66(35.15)$ & $<0.001$ \\
\hline$*$ Triglycerides $(\mathrm{TG})(\mathrm{mg} / \mathrm{dL})$ & $128.79(96.20)$ & $101.08(73.89)$ & $<0.001$ \\
\hline *Low density lipid cholesterol (LDL-C) (mg/dL) & $118.39(31.82)$ & $111.44(30.80)$ & $<0.001$ \\
\hline$*$ Creatinine $(\mathrm{mg} / \mathrm{dL})$ & $0.92(0.32)$ & $0.71(0.26)$ & $<0.001$ \\
\hline$*$ Uric acid $(\mathrm{mg} / \mathrm{dL})$ & $6.30(1.34)$ & $4.89(1.23)$ & $<0.001$ \\
\hline \multirow[t]{2}{*}{ *Albumin $(\mathrm{g} / \mathrm{dL})$} & $4.60(0.26)$ & $4.40(0.28)$ & $<0.001$ \\
\hline & $\begin{array}{l}\text { ACCA > cut-off value } \\
(\mathrm{N}=14284)\end{array}$ & $\begin{array}{l}\text { ACCA } \leq \text { cut-off value } \\
(\mathrm{N}=13080)\end{array}$ & \\
\hline *Serum calcium $(\mathrm{mg} / \mathrm{dL})$ & $9.46(0.35)$ & $9.19(0.36)$ & $<0.001$ \\
\hline Age (years) & $44.13(13.05)$ & $41.01(12.75)$ & 0.907 \\
\hline *Body mass index (BMI) $\left(\mathrm{kg} / \mathrm{m}^{2}\right)$ & $24.87(3.70)$ & $22.88(3.95)$ & $<0.001$ \\
\hline$*$ Total cholesterol $(\mathrm{mg} / \mathrm{dL})$ & $186.89(35.75)$ & $184.79(35.095)$ & $<0.001$ \\
\hline *Triglycerides (TG) (mg/dL) & $130.08(98.58)$ & $95.55(64.59)$ & $<0.001$ \\
\hline *Low density lipid cholesterol (LDL-C) (mg/dL) & $117.99(31.53)$ & $110.60(30.89)$ & $<0.001$ \\
\hline$*$ Creatinine $(\mathrm{mg} / \mathrm{dL})$ & $0.92(0.35)$ & $0.68(0.19)$ & $<0.001$ \\
\hline$*$ Uric acid $(\mathrm{mg} / \mathrm{dL})$ & $6.26(1.35)$ & $4.73(1.13)$ & $<0.001$ \\
\hline *Albumin $(\mathrm{g} / \mathrm{dL})$ & $4.53(0.29)$ & $4.45(0.28)$ & $<0.001$ \\
\hline
\end{tabular}

Table 1. Age and metabolic parameters as related to serum calcium level. ACCA, albumin corrected calcium. *Statistically significant variables es $(\mathrm{p}$ value $<0.05) * *$ Student's t-test.

\begin{tabular}{|c|c|c|c|c|c|c|c|c|c|c|c|c|}
\hline & \multicolumn{4}{|c|}{ Metabolic syndrome } & \multicolumn{4}{|c|}{ Diabetes mellitus } & \multicolumn{4}{|c|}{ Hypertension } \\
\hline & \multicolumn{2}{|l|}{ Model 1} & \multicolumn{2}{|l|}{ Model 2} & \multicolumn{2}{|l|}{ Model 1} & \multicolumn{2}{|l|}{ Model 2} & \multicolumn{2}{|l|}{ Model 1} & \multicolumn{2}{|l|}{ Model 2} \\
\hline & $\begin{array}{l}\text { OR }(95 \% \\
\text { CI })\end{array}$ & P value & $\begin{array}{l}\text { OR }(95 \% \\
\text { CI })\end{array}$ & P value & $\begin{array}{l}\text { OR }(95 \% \\
\text { CI) }\end{array}$ & P value & OR (95\% CI) & $P$ value & $\begin{array}{l}\text { OR }(95 \% \\
\text { CI })\end{array}$ & $P$ value & $\begin{array}{l}\text { OR }(95 \% \\
\text { CI })\end{array}$ & P value \\
\hline Total & $\begin{array}{l}* 1.17 \\
(1.05-1.30)\end{array}$ & 0.006 & $\begin{array}{l}1.13 \\
(1.00-1.29)\end{array}$ & 0.057 & $\begin{array}{l}* 1.32 \\
(1.10-1.57)\end{array}$ & 0.002 & $\begin{array}{l}* 1.40 \\
(1.16-1.68)\end{array}$ & $<0.001$ & $\begin{array}{l}* 1.37 \\
(1.24-1.52)\end{array}$ & $<0.001$ & $\begin{array}{l}* 1.14 \\
(1.03-1.27)\end{array}$ & 0.013 \\
\hline Male & $\begin{array}{l}1.01 \\
(0.89-1.15)\end{array}$ & 0.842 & $\begin{array}{l}1.08 \\
(0.93-1.25)\end{array}$ & 0.338 & $\begin{array}{l}* 1.23 \\
(1.01-1.50)\end{array}$ & 0.042 & $\begin{array}{l}* 1.35 \\
(1.10-1.67)\end{array}$ & 0.005 & $\begin{array}{l}* 1.23 \\
(1.09-1.38)\end{array}$ & 0.001 & $\begin{array}{l}1.10 \\
(0.98-1.25)\end{array}$ & 0.111 \\
\hline Female & $\begin{array}{l}* 1.52 \\
(1.23-1.90)\end{array}$ & $<0.001$ & $\begin{array}{l}1.26 \\
(0.96-1.65)\end{array}$ & 0.095 & $\begin{array}{l}* 1.65 \\
(1.16-2.34)\end{array}$ & 0.006 & $\begin{array}{l}* 1.50 \\
(1.03-2.18)\end{array}$ & 0.036 & $\begin{array}{l}* 1.63 \\
(1.33-2.00)\end{array}$ & $<0.001$ & \begin{tabular}{|l}
1.17 \\
$(0.94-1.45)$
\end{tabular} & 0.153 \\
\hline
\end{tabular}

Table 2. Relationship among serum calcium, MetS, diabetes, and hypertension in the cross-sectional study. MetS, Metabolic syndrome; OR, Odds ratio. Model 1: Adjusted for age, gender and body mass index (BMI); Model 2: Adjusted for age, gender, BMI, total cholesterol, triglycerides, LDL-C, creatinine, uric acid, serum albumin, proteinuria, and smoking status. Response variables: MetS or diabetes or hypertension status; Explanatory variables: Serum calcium level $(\mathrm{mg} / \mathrm{dL})$. *Statistically significant variables (p value $<0.05)$.

\section{Discussion}

Both higher total serum calcium and higher ACCA were associated with a higher prevalence of hypertension. In addition, high serum calcium and ACCA were strong predictors of future hypertension. As far as we know, this is the first longitudinal study to use plasma calcium as a predictor of hypertension. There are cross-sectional studies that support our results. A study of 12,406 U.S. adults found a positive correlation between serum total calcium level and hypertension ${ }^{10}$. Another study that included 12,865 and 14,293 Norwegian men and women, respectively, also found a positive correlation between serum calcium and blood pressure ${ }^{9}$. The influx of calcium into the smooth muscle of the artery leads to muscle contracture which increases vascular resistance and therefore could lead to development of hypertension. In addition, plasma calcium may be associated with shorter telomere length, which is linked to increased coronary artery calcium. The calcium component of coronary plaques leads to negative remodeling, resulting in a narrower vessel lumen, causing major adverse cardiovascular events ${ }^{14}$. Moreover, a positive correlation has been found between serum calcium and cholesterol, which are two important risk factors for hypertension development ${ }^{9}$. Several previous studies have found a positive correlation between $\mathrm{PTH}$ concentration and blood pressure ${ }^{15-17}$. PTH induces the reorganization and production of collagen by aortic vessel smooth muscle cells, leading to vascular wall thickening ${ }^{18}$.

Previous studies have suggested no correlation or a negative correlation between serum calcium and hypertension. For example, the study conducted by Hazari et al. concluded that serum calcium had no effect on hypertension $^{19}$. Unfortunately, their variables were not adjusted by age, BMI, total cholesterol, triglycerides, etc., as we have done. 


\begin{tabular}{|c|c|c|c|c|c|c|c|c|c|c|c|c|}
\hline & \multicolumn{4}{|c|}{ Metabolic syndrome } & \multicolumn{4}{|c|}{ Diabetes mellitus } & \multicolumn{4}{|l|}{ Hypertension } \\
\hline & \multicolumn{2}{|l|}{ Model 1} & \multicolumn{2}{|l|}{ Model 2} & \multicolumn{2}{|l|}{ Model 1} & \multicolumn{2}{|l|}{ Model 2} & \multicolumn{2}{|l|}{ Model 1} & \multicolumn{2}{|l|}{ Model 2} \\
\hline & OR $(95 \% \mathrm{CI})$ & P value & OR $(95 \% \mathrm{CI})$ & P value & OR (95\% CI) & \begin{tabular}{|l|} 
Pvalue \\
\end{tabular} & OR $(95 \% \mathrm{CI})$ & P value & OR $(95 \% \mathrm{CI})$ & Pvalue & OR $(95 \% \mathrm{CI})$ & P value \\
\hline Total & \begin{tabular}{|l|}
0.99 \\
$(0.86-1.13)$
\end{tabular} & 0.835 & $\begin{array}{l}* 1.20 \\
(1.03-1.40)\end{array}$ & 0.022 & $\begin{array}{l}* 1.49 \\
(1.20-1.85)\end{array}$ & $<0.001$ & $\begin{array}{l}* 1.76 \\
(1.41-2.20)\end{array}$ & $<0.001$ & $\begin{array}{l}1.12 \\
(0.99-1.28)\end{array}$ & 0.073 & $\begin{array}{l}* 1.15 \\
(1.01-1.30)\end{array}$ & 0.037 \\
\hline Male & $\begin{array}{l}* 0.76 \\
(0.62-0.93)\end{array}$ & 0.006 & $\begin{array}{l}* 1.30 \\
(1.03-1.64)\end{array}$ & 0.026 & $\begin{array}{l}* 1.43 \\
(1.00-2.04)\end{array}$ & 0.050 & $\begin{array}{l}* 1.68 \\
(1.17-2.42)\end{array}$ & 0.005 & $\begin{array}{l}1.05 \\
(0.87-1.27)\end{array}$ & 0.603 & $\begin{array}{l}1.10 \\
(0.90-1.33)\end{array}$ & 0.352 \\
\hline Female & $\begin{array}{l}1.12 \\
(0.94-1.34)\end{array}$ & 0.217 & $\begin{array}{l}1.08 \\
(0.87-1.34)\end{array}$ & 0.490 & $\begin{array}{l}* 1.52 \\
(1.15-2.00)\end{array}$ & 0.003 & $\begin{array}{l}* 1.86 \\
(1.39-2.49)\end{array}$ & $<0.001$ & $\begin{array}{l}1.08 \\
(0.91-1.29)\end{array}$ & 0.379 & \begin{tabular}{|l|}
1.15 \\
$(0.96-1.37)$
\end{tabular} & 0.129 \\
\hline
\end{tabular}

Table 3. Relationship among ACCA, MetS, diabetes, and hypertension in the cross-sectional study. MetS, Metabolic syndrome; ACCA, Albumin corrected calcium; OR, Odds ratio. Model 1: Adjusted for age, gender and body mass index (BMI); Model 2: Adjusted for age, gender, BMI, total cholesterol, triglycerides, LDL-C, creatinine, uric acid, serum albumin, proteinuria, and smoking status. Response variables: MetS or diabetes or hypertension status; Explanatory variables: ACCA level $(\mathrm{mg} / \mathrm{dL})$. *Statistically significant variables ( $\mathrm{p}$ value $<0.05)$.

\begin{tabular}{|c|c|c|c|c|c|c|c|c|c|c|c|c|}
\hline & \multicolumn{4}{|c|}{ Metabolic syndrome } & \multicolumn{4}{|c|}{ Diabetes mellitus } & \multicolumn{4}{|l|}{ Hypertension } \\
\hline & \multicolumn{2}{|l|}{ Model 1} & \multicolumn{2}{|l|}{ Model 2} & \multicolumn{2}{|l|}{ Model 1} & \multicolumn{2}{|l|}{ Model 2} & \multicolumn{2}{|l|}{ Model 1} & \multicolumn{2}{|l|}{ Model 2} \\
\hline & \multicolumn{4}{|l|}{ Events } & \multicolumn{4}{|l|}{ Events } & \multicolumn{4}{|l|}{ Events } \\
\hline & HR (95\% CI) & P value & HR (95\% CI) & $P$ value & HR (95\% CI) & P value & \begin{tabular}{|l} 
HR \\
$(95 \% \mathrm{CI})$
\end{tabular} & $P$ value & HR $(95 \% C I)$ & P value & HR (95\% CI) & $P$ value \\
\hline \multirow[b]{2}{*}{ Total } & \multicolumn{4}{|l|}{$\mathrm{N}=109$} & \multicolumn{4}{|l|}{$\mathrm{N}=53$} & \multicolumn{4}{|l|}{$N=165$} \\
\hline & $\begin{array}{l}* 1.67 \\
(1.08-2.58)\end{array}$ & 0.021 & $\begin{array}{l}* 1.73 \\
(1.07-2.79)\end{array}$ & 0.024 & $\begin{array}{l}* 2.23 \\
(1.21-4.12)\end{array}$ & 0.010 & $\begin{array}{l}* 2.51 \\
(1.30-4.83)\end{array}$ & 0.006 & $\begin{array}{l}* 1.50 \\
(1.06-2.13)\end{array}$ & 0.023 & $\begin{array}{l}* 1.76 \\
(1.22-2.55)\end{array}$ & 0.003 \\
\hline \multirow[b]{2}{*}{ Male } & \multicolumn{4}{|l|}{$\mathrm{N}=86$} & \multicolumn{4}{|l|}{$\mathrm{N}=42$} & \multicolumn{4}{|l|}{$\mathrm{N}=129$} \\
\hline & $\begin{array}{l}* 1.61 \\
(1.03-2.50)\end{array}$ & 0.036 & $\begin{array}{l}* 1.76 \\
(1.07-2.89)\end{array}$ & 0.027 & $\begin{array}{l}* 2.25 \\
(1.21-4.19)\end{array}$ & 0.011 & $\begin{array}{l}* 2.86 \\
(1.45-5.66)\end{array}$ & 0.003 & $\begin{array}{l}1.35 \\
(0.95-1.93)\end{array}$ & 0.096 & $\begin{array}{l}* 1.71 \\
(1.17-2.50)\end{array}$ & 0.006 \\
\hline \multirow[b]{2}{*}{ Female } & \multicolumn{4}{|l|}{$\mathrm{N}=23$} & \multicolumn{4}{|l|}{$\mathrm{N}=11$} & \multicolumn{4}{|l|}{$\mathrm{N}=36$} \\
\hline & - & - & - & - & - & - & - & - & $\begin{array}{l}* 12.42 \\
(3.39-45.49)\end{array}$ & $<0.001$ & $\begin{array}{l}* 5.35 \\
(1.14-25.03)\end{array}$ & 0.033 \\
\hline
\end{tabular}

Table 4. Multivariate hazard ratios of future MetS, diabetes, hypertension by serum calcium level. MetS, Metabolic syndrome; HR, Hazard ratio. Model 1: Adjusted for age, gender and body mass index (BMI); Model 2: Adjusted for age, gender, BMI, total cholesterol, triglycerides, LDL-C, creatinine, uric acid, serum albumin, proteinuria, and smoking status. Response variables: Incident MetS or diabetes or hypertension; Explanatory variables: Serum calcium level $(\mathrm{mg} / \mathrm{dL})$. *Statistically significant variables ( $\mathrm{p}$ value $<0.05)$.

Higher serum total calcium level and ACCA were associated with a higher prevalence of diabetes. High serum total calcium level and ACCA were good predictors of future diabetes in the total population and the male subgroup. There were too few events for development of diabetes in the female subgroup. Since the mean age of our study population was under average menopausal age, this result may be have been due to the protective effect of estrogen against insulin resistance ${ }^{20,21}$. The results are in accordance with most of the similar studies that have been conducted. Significantly higher serum calcium or ACCA level among diabetic subjects has been found in previous studies ${ }^{11,12,22}$. Sing et al. followed up 6096 participants for 59,130.9 persons-years while measuring serum total calcium and ACCA and found an association between elevated serum calcium concentration and incident diabetes ${ }^{23}$. Rooney et al. also obtained the same result by following 1516 participants for an average of 8.8 years $^{24}$. There are three possible mechanisms to explain this result. First, serum calcium is associated with insulin resistance in adipocytes and skeletal muscle as a result of a decreased number of glucose transporters ${ }^{24,25}$. Calcium-dependent enzymes and calcium channels are responsible for glucose uptake after insulin stimulates muscle cells ${ }^{12,26,27}$. Second, hypophosphatemia and hypercalcaemia often present simultaneously ${ }^{28}$. Previous studies have concluded that the relationship between low serum phosphate level and reduced insulin sensitivity is a result of impaired phosphorylation of carbohydrate intermediates in the glucose metabolism pathway ${ }^{29,30}$. Finally, a negative correlation was discovered between serum calcium and beta-cell function ${ }^{12}$. Studies have shown that disturbance of calcium homeostasis leads to impaired insulin secretion of beta-cells ${ }^{31}$.

Positive associations were found between ACCA and prevalence of MetS in the total population and among each gender. Positive associations were found between ACCA and prevalence of MetS in both partially and fully adjusted model of the male population. The risk of MetS was positively correlated to high serum calcium level and ACCA in the total population. The risk of MetS was positively correlated to high serum calcium level in the male population. We have already discussed the correlation between blood pressure, insulin resistance and calcium level above. Here we will focus on three other components of MetS: waist circumference (WC), TG, and HDL-C. A cross-sectional study conducted by Saltevo et al. randomly included 4500 middle-aged men and women and found that serum calcium level was associated with all of the MetS components except HDL-C ${ }^{13}$. Ahlström et al. included 1016 healthy individuals and found a positive correlation between plasma calcium and WC. In addition, the more criteria of the NCEP for metabolic syndrome were met, the higher the parathyroid hormone (PTH) level and ACCA were. PTH was positively associated with BMI, WC, SBP, DBP, TG, and insulin resistance and negatively associated with 


\begin{tabular}{|c|c|c|c|c|c|c|c|c|c|c|c|c|}
\hline & \multicolumn{4}{|c|}{ Metabolic syndrome } & \multicolumn{4}{|c|}{ Diabetes mellitus } & \multicolumn{4}{|l|}{ Hypertension } \\
\hline & \multicolumn{2}{|l|}{ Model 1} & \multicolumn{2}{|l|}{ Model 2} & \multicolumn{2}{|l|}{ Model 1} & \multicolumn{2}{|l|}{ Model 2} & \multicolumn{2}{|l|}{ Model 1} & \multicolumn{2}{|l|}{ Model 2} \\
\hline & \multicolumn{4}{|l|}{ Events } & \multicolumn{4}{|l|}{ Events } & \multicolumn{4}{|l|}{ Events } \\
\hline & $\begin{array}{l}\text { HR (95\% } \\
\text { CI) }\end{array}$ & $P$ value & $\begin{array}{l}\text { HR }(95 \% \\
\text { CI })\end{array}$ & $P$ value & $\operatorname{HR}(95 \% \mathrm{CI})$ & $P$ value & HR (95\% CI) & P value & $\begin{array}{l}\text { HR }(95 \% \\
\text { CI })\end{array}$ & $P$ value & HR (95\% CI) & $P$ value \\
\hline \multirow[b]{2}{*}{ Total } & \multicolumn{4}{|l|}{$\mathrm{N}=109$} & \multicolumn{4}{|l|}{$\mathrm{N}=53$} & \multicolumn{4}{|l|}{$\mathrm{N}=165$} \\
\hline & $\begin{array}{l}* 1.774 \\
(1.12-2.80)\end{array}$ & 0.014 & $\begin{array}{l}* 1.69 \\
(1.04-2.74)\end{array}$ & 0.035 & $\begin{array}{l}* 3.01 \\
(1.50-6.03)\end{array}$ & 0.002 & $\begin{array}{l}* 2.95 \\
(1.43-6.07)\end{array}$ & 0.003 & $\begin{array}{l}* 1.93 \\
(1.33-2.80)\end{array}$ & 0.001 & $\begin{array}{l}* 2.07 \\
(1.41-3.02)\end{array}$ & $<0.001$ \\
\hline \multirow[b]{2}{*}{ Male } & \multicolumn{4}{|l|}{$\mathrm{N}=86$} & \multicolumn{4}{|l|}{$\mathrm{N}=42$} & \multicolumn{4}{|l|}{$\mathrm{N}=129$} \\
\hline & $\begin{array}{l}* 1.74 \\
(1.08-2.80)\end{array}$ & 0.024 & $\begin{array}{l}1.63 \\
(0.99-2.69)\end{array}$ & 0.057 & $\begin{array}{l}* 3.46 \\
(1.63-7.33)\end{array}$ & 0.001 & $\begin{array}{l}* 3.39 \\
(1.57-7.33)\end{array}$ & 0.002 & $\begin{array}{l}* 1.61 \\
(1.11-2.35)\end{array}$ & 0.013 & $\begin{array}{l}* 1.72 \\
(1.17-2.53)\end{array}$ & 0.006 \\
\hline \multirow[b]{2}{*}{ Female } & \multicolumn{4}{|l|}{$\mathrm{N}=23$} & \multicolumn{4}{|l|}{$\mathrm{N}=11$} & \multicolumn{4}{|l|}{$\mathrm{N}=36$} \\
\hline & $\begin{array}{l}1.92 \\
(0.24-15.50)\end{array}$ & 0.542 & $\begin{array}{l}2.19 \\
(0.22-21.66)\end{array}$ & 0.504 & - & - & - & - & $\begin{array}{l}* 9.46 \\
(3.64-24.59)\end{array}$ & $<0.001$ & $\begin{array}{l}* 11.40 \\
(3.22-40.44)\end{array}$ & $<0.001$ \\
\hline
\end{tabular}

Table 5. Multivariate hazard ratios of future MetS, diabetes, hypertension by ACCA level. MetS, Metabolic syndrome; ACCA, Albumin corrected calcium; HR, Hazard ratio. Model 1: Adjusted for age, gender and body mass index (BMI); Model 2: Adjusted for age, gender, BMI, total cholesterol, triglycerides, LDL-C, creatinine, uric acid, serum albumin, proteinuria, and smoking status. Response variables: Incident MetS or diabetes or hypertension; Explanatory variables: ACCA (mg/dL). *Statistically significant variables (p value $<0.05)$.

HDL-C ${ }^{17}$. PTH plays a crucial role in the development of MetS components. A previous study revealed that individuals with higher PTH level had a higher chance of developing metabolic obesity ${ }^{32}$. Part of this can be explained by the insulin resistance effect caused by PTH, or serum calcium as we have mentioned above. Moreover, the dyslipidemia consequence of higher PTH level can also be attributed to central obesity ${ }^{32}$. A significant association has been found between serum calcium and unfavorable lipid profile, including triglycerides and HDL- $\mathrm{C}^{33}$. Conversely, serum calcium impairs cholesterol catabolism in the liver and increases lipid synthesis ${ }^{34,35}$. With regard to HDL-C, a previous study indicated no correlation between HDL-C and serum calcium ${ }^{13}$. To the best of our knowledge, the mechanism involved in the association between HDL-C and serum calcium is still not well understood. Some studies have hypothesized that the sterol regulatory element-binding protein (SREBP) pathway plays a key role in HDL-C $C^{9,33,36}$. In addition to the SREBP pathway, the relationship between PTH and HDL-C is again highlighted ${ }^{17}$. PTH level has been correlated with several inflammatory markers ${ }^{37}$. The link between inflammation and MetS has been reported, for example, an inflammatory diet pattern is associated with MetS and its components.

There are several limitations to our study. First, we did not measure ionized calcium, which is the most active form of calcium. Although we applied ACCA, there are studies that suggest ionized calcium is a better indicator of the serum calcium status ${ }^{38,39}$. Second, this would have been a more complete study if we had taken the level of PTH into account, since previous studies have shown a strong relationship between PTH level and MetS components ${ }^{17,24}$. Third, because serum calcium and phosphorous levels are closely related, we should also take the phosphorus level into consideration ${ }^{28-30}$. Fourth, there were too few events for the development of MetS and diabetes in the female subgroup. Fifth, we could not ensure all participants fasted for at least 8 hours. Last but not least, our study population was composed of mostly Chinese and lacked other ethnicities, such as Africans or Caucasians, who have shown different efficiencies on calcium metabolism ${ }^{24}$.

\section{Conclusion}

Higher serum calcium and ACCA are associated with an increased risk of developing MetS, diabetes, and hypertension, especially among the male population. Serum calcium and ACCA are associated with increased prevalence of MetS, diabetes, and hypertension. Strength of the study includes 1. Large study sample was included 2. The adjustment for potential confounders were performed 3. The study included much discussion of the prior literature on the topic. Further research with international comparisons and discussion is needed to better establish the association between serum calcium level and cardiometabolic diseases.

\section{Methods}

Study design and population. We acquired data from participants who received health exams at Tri-Service General Hospital (TSGH), Taiwan during the period 2010 to 2016. There were 27,364 eligible subjects aged 20 years of age and older. Our study was approved by Institutional Review Board (IRB) of TSGH. The IRB waived the need to obtain individual informed consent because the data were analyzed anonymously. Participants enrolled were analyzed according to following steps. First of all, baseline characteristics were determined. In the cross-sectional study, optimal cut-off values for serum calcium and ACCA to predict the future development of cardiometabolic diseases were obtained respectively for gender difference using receiver operating characteristic curves (ROC). Next, the exclusion criteria of the cohort study included those with baseline MetS, diabetes, hypertension or other systemic diseases $(n=5,234)$, subjects with only one visit $(n=10,230)$, subjects with insufficient data at end-point $(\mathrm{n}=1,820)$. Finally, there were 10,080 participants. Multivariate longitudinal analysis were conducted to examine whether higher serum calcium or ACCA level were associated with higher incident rate of cardiometabolic diseases.

Defining criteria for metabolic syndrome. According to MetS criteria defined by the 2005 revised NCEP ATP III, MetS is comprised of at least 3 of the following 5 components: (1) plasma triglycerides $\geq 150 \mathrm{mg} / \mathrm{dl}$ 
$(1.7 \mathrm{mmol} / \mathrm{L})$ or under treatment (2) HDL cholesterol $<40 \mathrm{mg} / \mathrm{dl}(1.03 \mathrm{mmol} / \mathrm{l})$ in $\mathrm{men},<50 \mathrm{mg} / \mathrm{dL}(1.29 \mathrm{mmol} / \mathrm{l})$ in women or under treatment (3) systolic blood pressure $\geq 130 \mathrm{~mm} \mathrm{Hg}$ and/or diastolic blood pressure $\geq 85 \mathrm{~mm}$ $\mathrm{Hg}$ or under treatment (4) fasting plasma glucose $\geq 100 \mathrm{mg} / \mathrm{dl}$, under treatment, or previously diagnosed with diabetes mellitus (5) waist circumference cutoffs modified for Asian populations, $\geq 90 \mathrm{~cm}$ in men or $\geq 80 \mathrm{~cm}$ in women $^{40}$.

Definition of hypertension. Based on the Seventh Report of the Joint National Committee on Prevention, Detection, Evaluation, and Treatment of High Blood Pressure, hypertension is defined as blood pressure higher than $140 / 90 \mathrm{mmHg}$ or subjects have already been taking antihypertensive agents ${ }^{41}$.

Definition of type 2 diabetes. Based on the 2019 American Diabetes Association (ADA) "Standards of Medical Care in Diabetes", type 2 diabetes is defined as random plasma glucose $\geq 200 \mathrm{mg} / \mathrm{dL}$ with symptoms (polydipsia, polyphagia, polyuria, and weight loss) or raised value measured twice. Fasting plasma glucose $\geq 126 \mathrm{mg} / \mathrm{dL}$ can also lead to diagnosis. In addition, those already taking anti-diabetic agents are also considered to have type 2 diabetes $^{42}$.

Assessment of covariates. Health examination includes physical and mental status evaluation, anthropometric measurements, and comprehensive biochemistry tests. Participants were fasted for at least 8 hours prior to phlebotomy. Biochemistry tests are composed of blood cell counts, concentration of blood urea nitrogen, serum creatinine, aspartate transaminase (AST), alanine transaminase (ALT), total calcium, serum albumin, fasting glucose, total cholesterol, high-density lipoprotein cholesterol (HDL-C), low density lipoprotein cholesterol (LDL-C), triglycerides, serum uric acid, and urinalysis. Fasting blood sample was drawn between 7:30 am and 11:00 am and stored in a $4^{\circ} \mathrm{C}$ refrigerator immediately ${ }^{43}$. We applied the o-cresolphthalein complexone method to obtain serum calcium level. ACCA was calculated by using [serum calcium $+0.8 \times(4$-serum albumin)]. The unit for serum calcium and ACCA is mg/dL. Blood pressure was taken after participants have received at least 10 -min of rest. Participants were seated with a sphygmomanometer placed on right arm. Waist circumference was measured at the middle point between iliac crest and $12^{\text {th }}$ rib.

Statistical analysis. SPSS (version 18.0 for Windows; SPSS Inc., Chicago, IL, USA) was used as the software for statistical analysis. Optimal cut-off values of serum calcium level and ACCA for the male and female participants respectively were calculated by ROC. At baseline, participants were divided into two subgroups according to the cut-off values of serum calcium and ACCA. Student's t-test was performed to evaluate the difference of continuous characteristics at baseline between the two groups. Data was shown as mean \pm standard deviation and the distribution normalized with Kolmogorov-Smirnov test. Two-sided P-value less than 0.05 was considered statistically significant. Logistic regression for calculating OR was used to determine association between serum calcium or ACCA level and MetS, diabetes, hypertension at baseline. Univariate and multivariate Cox proportional hazard models were applied to obtain the HR of both groups during the follow-up period to find out whether serum calcium or ACCA exceeding the cut-off values were associated with increased risk of developing MetS, diabetes, and hypertension. In our study, two models were investigated as follows. Model 1 was adjusted for age, gender and BMI. Model 2 was adjusted for age, gender, BMI, total cholesterol, triglycerides, LDL-C, creatinine, uric acid, serum albumin, proteinuria, and smoking status.

Received: 23 May 2018; Accepted: 10 February 2020;

Published online: 21 February 2020

\section{References}

1. O’Neill, S. \& O’Driscoll, L. Metabolic syndrome: a closer look at the growing epidemic and its associated pathologies. Obesity reviews: an official journal of the International Association for the Study of Obesity 16, 1-12, https://doi.org/10.1111/obr.12229 (2015).

2. Lago, R. M., Singh, P. P. \& Nesto, R. W. Diabetes and hypertension. Nature Clinical Practice Endocrinology \&Amp; Metabolism 3, 667, https://doi.org/10.1038/ncpendmet0638, https://www.nature.com/articles/ncpendmet0638\#supplementary-information (2007).

3. Beto, J. A. The Role of Calcium in Human Aging. Clinical Nutrition Research 4, 1-8, https://doi.org/10.7762/cnr.2015.4.1.1 (2015).

4. Landsberg, L. \& Molitch, M. Diabetes and hypertension: pathogenesis, prevention and treatment. Clinical and experimental hypertension (New York, N.Y.: 1993) 26, 621-628 (2004).

5. Cheung, B. M. Y. \& Li, C. Diabetes and Hypertension: Is There a Common Metabolic Pathway? Current Atherosclerosis Reports 14, 160-166, https://doi.org/10.1007/s11883-012-0227-2 (2012).

6. Scholze, J. et al. Epidemiological and economic burden of metabolic syndrome and its consequences in patients with hypertension in Germany, Spain and Italy; a prevalence-based model. BMC Public Health 10, 529-529, https://doi.org/10.1186/1471-2458-10-529 (2010).

7. Jadhav, U. M. Cardio-metabolic disease in India-the up-coming tsunami. Ann Transl Med 6, 295-295, https://doi.org/10.21037/ atm.2018.06.47 (2018).

8. Lo, W. C. et al. Adult mortality of diseases and injuries attributable to selected metabolic, lifestyle, environmental, and infectious risk factors in Taiwan: a comparative risk assessment. Population health metrics 15, 17, https://doi.org/10.1186/s12963-017-0134-4 (2017).

9. Jorde, R., Sundsfjord, J., Fitzgerald, P. \& Bonaa, K. H. Serum calcium and cardiovascular risk factors and diseases: the Tromso study. Hypertension (Dallas, Tex.: 1979) 34, 484-490 (1999).

10. Sabanayagam, C. \& Shankar, A. Serum calcium levels and hypertension among U.S. adults. Journal of clinical hypertension (Greenwich, Conn.) 13, 716-721, https://doi.org/10.1111/j.1751-7176.2011.00503.x (2011).

11. Yamaguchi, T., Kanazawa, I., Takaoka, S. \& Sugimoto, T. Serum calcium is positively correlated with fasting plasma glucose and insulin resistance, independent of parathyroid hormone, in male patients with type 2 diabetes mellitus. Metabolism: clinical and experimental 60, 1334-1339, https://doi.org/10.1016/j.metabol.2011.02.003 (2011).

12. Sun, G., Vasdev, S., Martin, G. R., Gadag, V. \& Zhang, H. Altered calcium homeostasis is correlated with abnormalities of fasting serum glucose, insulin resistance, and beta-cell function in the Newfoundland population. Diabetes 54, 3336-3339 (2005). 
13. Saltevo, J. et al. Serum calcium level is associated with metabolic syndrome in the general population: FIN-D2D study. European journal of endocrinology 165, 429-434, https://doi.org/10.1530/eje-11-0066 (2011).

14. O'Callaghan, N. J., Bull, C. \& Fenech, M. Elevated plasma magnesium and calcium may be associated with shorter telomeres in older South Australian women. The journal of nutrition, health \& aging 18, 131-136, https://doi.org/10.1007/s12603-013-0401-4 (2014).

15. Snijder, M. B. et al. Vitamin D status and parathyroid hormone levels in relation to blood pressure: a population-based study in older men and women. Journal of internal medicine 261, 558-565, https://doi.org/10.1111/j.1365-2796.2007.01778.x (2007).

16. Saleh, F., Jorde, R., Svartberg, J. \& Sundsford, J. The relationship between blood pressure and serum parathyroid hormone with special reference to urinary calcium excretion: The Tromsø study. Journal of Endocrinological Investigation 29, 214-220, https://doi. org/10.1007/BF03345542 (2006).

17. Ahlström, T. et al. Correlation between plasma calcium, parathyroid hormone (PTH) and the metabolic syndrome (MetS) in a community-based cohort of men and women. Clin Endocrinol (Oxf) 71, 673-678, https://doi.org/10.1111/j.1365-2265.2009.03558.x (2009).

18. Perkovic, V. et al. Parathyroid hormone has a prosclerotic effect on vascular smooth muscle cells. Kidney \& blood pressure research 26, 27-33, doi:69761 (2003).

19. Hazari, M. A. H., Arifuddin, M. S., Muzzakar, S. \& Reddy, V. D. Serum Calcium Level in Hypertension. North American Journal of Medical Sciences 4, 569-572, https://doi.org/10.4103/1947-2714.103316 (2012).

20. Suba, Z. Interplay between insulin resistance and estrogen deficiency as co- activators in carcinogenesis. Pathology oncology research: POR 18, 123-133, https://doi.org/10.1007/s12253-011-9466-8 (2012).

21. Vogel, H. et al. Estrogen deficiency aggravates insulin resistance and induces beta-cell loss and diabetes in female New Zealand obese mice. Hormone and metabolic research = Hormon- und Stoffwechselforschung = Hormones et metabolisme 45, 430-435, https:// doi.org/10.1055/s-0032-1331700 (2013).

22. Becerra-Tomás, N. et al. Increased Serum Calcium Levels and Risk of Type 2 Diabetes in Individuals at High Cardiovascular Risk. Diabetes Care 37, 3084-3091, https://doi.org/10.2337/dc14-0898 (2014).

23. Sing, C. W. et al. Serum calcium and incident diabetes: an observational study and meta-analysis. Osteoporosis international: a journal established as result of cooperation between the European Foundation for Osteoporosis and the National Osteoporosis Foundation of the USA 27, 1747-1754, https://doi.org/10.1007/s00198-015-3444-z (2016).

24. Rooney, M. R. et al. Serum calcium and incident type 2 diabetes: the Atherosclerosis Risk in Communities (ARIC) study. The American journal of clinical nutrition 104, 1023-1029, https://doi.org/10.3945/ajcn.115.130021 (2016).

25. Begum, N., Leitner, W., Reusch, J. E., Sussman, K. E. \& Draznin, B. GLUT-4 phosphorylation and its intrinsic activity. Mechanism of $\mathrm{Ca}(2+)$-induced inhibition of insulin-stimulated glucose transport. The Journal of biological chemistry 268, 3352-3356 (1993).

26. Ojuka, E. O. Role of calcium and AMP kinase in the regulation of mitochondrial biogenesis and GLUT4 levels in muscle. The Proceedings of the Nutrition Society 63, 275-278, https://doi.org/10.1079/pns2004339 (2004).

27. Wright, D. C., Hucker, K. A., Holloszy, J. O. \& Han, D. H. Ca2+ and AMPK both mediate stimulation of glucose transport by muscle contractions. Diabetes 53, 330-335 (2004).

28. Hagström, E., Hellman, P., Lundgren, E., Lind, L. \& Ärnlöv, J. Serum calcium is independently associated with insulin sensitivity measured with euglycaemic-hyperinsulinaemic clamp in a community-based cohort. Diabetologia 50, 317-324, https://doi. org/10.1007/s00125-006-0532-9 (2007)

29. Haap, M. et al. Association of serum phosphate levels with glucose tolerance, insulin sensitivity and insulin secretion in non-diabetic subjects. European journal of clinical nutrition 60, 734-739, https://doi.org/10.1038/sj.ejcn.1602375 (2006).

30. Xie, W., Tran, T. L., Finegood, D. T. \& van de Werve, G. Dietary P(i) deprivation in rats affects liver cAMP, glycogen, key steps of gluconeogenesis and glucose production. The Biochemical journal 352 Pt 1, 227-232 (2000).

31. Rorsman, P., Braun, M. \& Zhang, Q. Regulation of calcium in pancreatic $\alpha$ - and $\beta$-cells in health and disease. Cell Calcium 51, 300-308, https://doi.org/10.1016/j.ceca.2011.11.006 (2012).

32. Ha, J. et al. Parathyroid hormone and vitamin D are associated with the risk of metabolic obesity in a middle-aged and older Korean population with preserved renal function: A cross-sectional study. Plos One 12, e0175132, https://doi.org/10.1371/journal. pone.0175132 (2017)

33. Gallo, L. et al. Serum Calcium Increase Correlates With Worsening of Lipid Profile: An Observational Study on a Large Cohort From South Italy. Medicine 95, e2774, https://doi.org/10.1097/MD.0000000000002774 (2016).

34. Revankar, C. M., Cimino, D. F., Sklar, L. A., Arterburn, J. B. \& Prossnitz, E. R. A transmembrane intracellular estrogen receptor mediates rapid cell signaling. Science (New York, N.Y.) 307, 1625-1630, https://doi.org/10.1126/science.1106943 (2005).

35. Goldstein, J. L. \& Brown, M. S. Regulation of the mevalonate pathway. Nature 343, 425-430, https://doi.org/10.1038/343425a0 (1990).

36. Kivelä, A. M. et al. Regulation of endothelial lipase and systemic HDL cholesterol levels by SREBPs and VEGF-A. Atherosclerosis 225, 335-340, https://doi.org/10.1016/j.atherosclerosis.2012.09.039 (2012).

37. Cheng, S.-P., Liu, C.-L., Liu, T.-P., Hsu, Y.-C. \& Lee, J.-J. Association between Parathyroid Hormone Levels and Inflammatory Markers among US Adults. Vol. 2014 (2014).

38. Gouri, A. \& Dekaken, A. A comparison of corrected serum calcium levels to ionized calcium levels in haemodialysis patients. Annales de biologie clinique 70, 210-212, https://doi.org/10.1684/abc.2012.0693 (2012).

39. Sava, L., Pillai, S., More, U. \& Sontakke, A. Serum calcium measurement: Total versus free (ionized) calcium. Indian Journal of Clinical Biochemistry 20, 158-161, https://doi.org/10.1007/BF02867418 (2005).

40. Grundy, S. M. et al. Diagnosis and management of the metabolic syndrome: an American Heart Association/National Heart, Lung, and Blood Institute scientific statement. Circulation 112, 2735-2752 (2005).

41. Chobanian, A. V. et al. Seventh report of the Joint National Committee on Prevention, Detection, Evaluation, and Treatment of High Blood Pressure. Hypertension (Dallas, Tex.: 1979) 42, 1206-1252, https://doi.org/10.1161/01.HYP.0000107251.49515.c2 (2003).

42. 2. Classification and Diagnosis of Diabetes: \&lt;em\&gt;Standards of Medical Care in Diabetes-2019\&lt;/em\&gt. Diabetes Care 42, S13, https://doi.org/10.2337/dc19-S002 (2019).

43. Li, W.-C. et al. Waist-to-height ratio, waist circumference, and body mass index as indices of cardiometabolic risk among 36,642 Taiwanese adults. European Journal of Nutrition 52, 57-65, https://doi.org/10.1007/s00394-011-0286-0 (2013).

\section{Author contributions}

Cheng-Wai Chou contributed to the design of the study, was responsible for the management and retrieval of data, contributed to initial data analysis and interpretation, drafted the initial manuscript. Cheng-Wai Chou, Wen-Hui Fang, Yuan-Yuei Chen, Chung-Ching Wang, Tung-Wei Kao, Chen-Jung Wu, and Wei-Liang Chen decided upon the data collection methods. Cheng-Wai Chou and Wei-Liang Chen were also responsible for the data analysis decisions. Wei-Liang Chen conceptualized and designed the study, supervised all aspects of the study, critically reviewed and revised the manuscript, and approved the final manuscript as submitted. All authors meet the ICMJE criteria for authorship. 


\section{Competing interests}

The authors declare no competing interests.

\section{Additional information}

Correspondence and requests for materials should be addressed to W.-L.C.

Reprints and permissions information is available at www.nature.com/reprints.

Publisher's note Springer Nature remains neutral with regard to jurisdictional claims in published maps and institutional affiliations.

(c) (i) Open Access This article is licensed under a Creative Commons Attribution 4.0 International License, which permits use, sharing, adaptation, distribution and reproduction in any medium or format, as long as you give appropriate credit to the original author(s) and the source, provide a link to the Creative Commons license, and indicate if changes were made. The images or other third party material in this article are included in the article's Creative Commons license, unless indicated otherwise in a credit line to the material. If material is not included in the article's Creative Commons license and your intended use is not permitted by statutory regulation or exceeds the permitted use, you will need to obtain permission directly from the copyright holder. To view a copy of this license, visit http://creativecommons.org/licenses/by/4.0/.

(c) The Author(s) 2020 